\title{
Keratin Filament
}

National Cancer Institute

\section{Source}

National Cancer Institute. Keratin Filament. NCI Thesaurus. Code C13368.

A class of intermediate filaments that form a network within epithelial cells and anchor to desmosomes, thus imparting tensile strength to the tissue 